\title{
ПРОБЛЕМИ ДОСЛІДЖЕННЯ БАЯННО-АКОРДЕОННОГО МИСТЕЦТВА УКРАЇНИ: НАЦІОНАЛЬНІ ТА МІЖНАРОДНІ РЕПЕРТУАРНІ ТЕНДЕНЦІЇ
}

\author{
Улич (Савчин) Г. В.
}

\section{ВСТУП}

Сучасний етап модернізації музичної світи України сприяє виявленню та впровадженню новітніх елементів існування та функціонування феномену. Це безпосередньо впливає на загальну структуру музичного мистецтва в галузі теорії та методики й активно проявляється в інструментальній складовій частині. Важлива роль у цілісній музичній i музикознавчій галузі належить народним інструментам i їхній пріоритетній баянно-акордеонній складовій частині, які сьогодні мають сформовану науково-практичну школу виховання висококваліфікованих музикантів-професіоналів. Тут, беззаперечно, ключова увага індивіда зосереджена на теорії формування виконавської майстерності баяніста-акордеоніста (автор М. Давидов). На її основі здійснено низку досліджень:

- y cфері баяна - «Художні тенденції розвитку академічного баянного виконавства у другій половині XX ст.» (Д. Кужелєв), «Фактура у виявленні виражальних властивостей баянної музики» (А. Черноіваненко), «Еволюція виконавської техніки в українській баянній школі (друга половина XX ст.)» (Вл. Князєв), «Принципи та фактори артикуляції у виконанні на баяні» (В. Дорохін), «Баянне мистецтво в музичній культурі України (друга половина XX ст.)» (Р. Безугла), «Естрадно-джазова музика в акордеонно-баянному мистецтві України другої половини XX - початку XXI ст.: композиторська творчість і виконавство» (М. Булда), «Творчість Володимира Зубицького в контексті розвитку сучасного баянного репертуару» (Г. Голяка), «Науково-практична школа М. А. Давидова як феномен формування виконавської майстерності баяніста» (В. Заєць), «Інтерпретація музики бароко на баяні (теоретико-виконавський аспект)» (С. Карась) та ін.;

- y сфері колективного музикування на народних інструментах «Баянний ансамблево-оркестровий інструменталізм в історичній стильовій проекції» (С. Калмиков), «Академічне народно-інструментальне ансамблеве мистецтво України XX ст.: історико-виконавський аспект» 
(Л. Пасічняк), «Феномен колективного народно-інструментального музикування західноукраїнського регіону» (П. Дрозда), «Темброва еволюція в українській народно-оркестровій музиці» (О. Трофимук), «Культурно-історична еволюція українського оркестру народних інструментів» (Т. Сідлецька), «Методика організації та роботи підліткового класичного ансамблю гітаристів» (В. Грищенко) та ін.

Важливо також відзначити докторську дисертацію «Специфіка виражальних засобів в українській музиці для баяна (остання чверть XX - перше десятиріччя XXI ст.)» А. Сташевського (2014), що продовжила формування наукової школи у галузі баяна-акордеона та створила фундамент для нових досліджень.

Варта уваги низка навчальних i методичних посібників, підручників, довідників, енциклопедичне видання «Виконавське музикознавство» М. Давидова (Луцьк, 2010), збірники тез і матеріалів науково-практичних конференцій (щодо нашого дослідження, то варто відзначити «Творчість для народних інструментів композиторів України та зарубіжжя» й «Народно-інструментальне мистецтво на зламі XX-XXI ст.», котрі систематично проводяться у Дрогобичі), новітніх компонувань для народних інструментів створених українськими композиторами-сучасниками, тощо.

Серед фундаментальних праць, у яких фігурує репертуарна складова частина, ми назвемо: підручник М. Давидова «Історія виконавства на народних інструментах (Українська академічна школа)» (Київ, 2010); посібникова література А. Сташевського «Володимир Рунчак - "Музика про життя...”. Аналітичні есе баянної творчості» (Луцьк, 2004), «Нариси з історії української музики для баяна» (Луганськ, 2006) i «Великі жанри в українській музиці для баяна та акордеона (тенденції розвитку в останній чверті XX та на початку XXI ст.)» (Луганськ, 2007), А. Душного «Анатолій Онуфрієнко: життя присвячене музиці» (Дрогобич, 2010), Д. Кужелева «Баянна творчість українських композиторів» (Львів, 2011) та ін.; довідникові видання «Баянно-акордеонне мистецтво України на зламі XX - XXI ст.» А. Семешка (Тернопіль, 2009), «Львівська школа баянно-акордеонного мистецтва» А. Душного та Б. Пица (Дрогобич, 2010), «Світова баянно-акордеонна література на зламі XX - XXI ст.» А. Семешка (Вінниця, 2015) та ін.

Гроно творчих портретів українських композиторів-баяністів у формі діалогів окреслено А. Семешком «Володимир Подгорний: один погляд на портрет художника» (Київ, 2003), «Діалог про час та майстерність 3 В. Зубицьким» (Київ, 2003), «Анатолій Гайденко» (Київ, 2004), «Володимир Рунчак» (Київ, 2004), «Віктор Власов» (Київ, 2004) та ін., у яких аналізуються особливості творчості композиторів України на зламі століть. 


\section{1. Репертуарний дискурс у наукових студіях XXI ст. (український і зарубіжний досвід)}

Репертуарні уподобання - тематика дослідження науковців різних сфер музичного мистецтва. Не винятком у цьому розмаїтті $\epsilon$ і творчість для баяна й акордеона як українських, так і зарубіжних композиторів. Входження баяна-акордеона в академічно русло стало запорукою усестороннього наукового осмислення функціонування інструменту у соціокультурному просторі на зламі століть.

Одним із пріоритетів визнання баяна-акордеона академічним інструментом $є$ репертуар, формування якого бере початок від 40-х рр. $\mathrm{XX}$ ст. а із постійним вдосконаленням інструменту - i написання оригінальної музики. Водночас покоління професійних композиторівбаяністів (таких як В. Зубицький, В. Золотарьов, В. Власов, В. Рунчак, В. Семенов, А. Білошицький, А. Сташевський, Я. Олексів, Б. Мирончук та ін.) сприяло як створенню оригінальних компонувань, так i камернізації інструменту у напрямі розмаїття творчого експерименту щодо репертуару та залучення баяна-акордеона до найрізноманітнішого колективного музикування.

Репертуарні тенденції баянно-акордеонного мистецтва в Україні активно досліджують науковці В. Власов, А. Сташевський, Г. Голяка, О. Гончаров, А. Душний, В. Дорохін, В. Мурза, С. Карась, О. Карась, Ю. Дякунчак, Я. Олексів, М. Булда, Л. Пасічняк, Р. Кундис, Ю. Чумак, А. Шамігов та ін. Захищено низку дисертацій із питань репертуару, творчості, особистостей окресленої сфери (Р. Безугла, М. Булда ${ }^{1}$, Г. Голяка, О. Гончаров ${ }^{2}$, Д. Кужелєв, Я. Олексів ${ }^{3}$, А. Сташевський ${ }^{4}$, А. Шамігов ${ }^{5}$, Ю. Чумак ${ }^{6}$, А. Нижник та ін.), видано фундаментальні

${ }^{1}$ Булда М. Естрадно-джазова музика в акордеонно-баянному мистецтві України другої половини XX - початку XXI століття: композиторська творчість і виконавство : автореф. дис. .... канд. мистецтвознавства : 17.00.03. Харків, 2007. 22 с.

${ }^{2}$ Гончаров А. Неофольклористичні тенденції у баянній творчості В. Зубицького : автореф. дис. ... канд. мистецтвознав. : 17.00.03. Київ, 2006. 17 с.

Олексів Я. Рецепція жанрів сюїти і партити в українській баянній музиці другої половини ХX століття : автореф. дис. ... канд. мистецтвознав. : 17.00.03. Львів, 2011. 20 с.

${ }^{4}$ Сташевський А. Специфіка виражальних засобів в українській музиці для баяна (остання чверть XX - перше десятиріччя XXI ст.) : автореф. дис. ... доктора мистецтвознав. : 17.00.03. Київ, 2014. 36 с.

5 Шамігов А. Особливості опосередкування фольклору в оригінальній музиці українських композиторів для баяна соло (фольклорний неоромантизм, неофольклоризм, нова фольклорна хвиля) : автореф. дис. ... канд. мистецтвознав. : 26.00.01. Київ, 2011. 16 с.

6 Чумак Ю. Творчість Віктора Власова в контексті баянно-акордеонної музики України : автореф. дис. ... канд. мистецтвознав. : 17.00.03. Одеса, 2014. 19 с. 
праці (А. Семешко, А. Сташевський, А. Душний ${ }^{7}$, Д. Кужелєв, М. Черепанин ${ }^{8}$ та ін.) та довідникову літературу (М. Давидов, А. Семешко, А. Душний і Б. Пиц), ведеться систематична інтеграція баянно-акордеонної спільноти України у міжнародний соціокультурний простір XXI ст.

У Росії цю сферу популяризують праці М. Імханіцкого, Ф. Ліпса, В. Семенова, В. Васильєва, Р. Бажиліна, В. Голубнічого, Є. Суслова ${ }^{9}$, Л. Варавіної ${ }^{10}$ ， А. Лєбєдєва， 3. Смакової, А. Гайсіна та ін. Відомі дисертаційні дослідження А. Михайлової «Фольклорні та нефольклорні стильові тенденції в музиці вітчизняних композиторів для баяна» (Саратов, 2006), У. Міронової «Твори Софії Губайдуліної для баяна» (Москва, 2008), Т. Буданової «Стильові тенденції в музиці для баяна композиторів Сибіру та Далекого Сходу (друга половина 1970-х 2000-і рр.)» (Владивосток, 2009), О. Васільєва «Баян в сучасному ансамблі: образні та темброві пошуки вітчизняних композиторів (остання четверть XX - початок XXI ст.)» (Саратов, 2012), М. Власової «Творчість Михайла Броннера для баяна» (Москва, 2013).

У царині репертуару - пріоритетна посібникова література М. Імханіцкого «Музика зарубіжних композиторів для баяна й акордеона» (Москва, 2004) та «Історія баянного й акордеонного мистецтва» (Москва, 2006), яка стала грунтовним напрацюванням і методичним архівом сучасного викладача. Зазначені праці презентувалися автором на майстеркласах i методичних семінарах у рамках I міжнародного конкурсу баяністів-акордеоністів «Акорди Львова» (Львів, 2006) i IV конкурсу «Perpetuum mobile» (Дрогобич, 2011).

Щодо першого видання, то воно апелює до вивчення історії становлення та розвитку акордеонного мистецтва у країнах Європи та

7 Душний А. Анатолій Онуфрієнко: життя присвячене музиці : монографія / за заг. ред. Б. Пица. Дрогобич : Посвіт, 2010. 328 с.

8 Черепанин М., Булда М. Естрадний олімп акордеона : монографія. Івано-Франківськ : Видавництво «Лілея-НВ», 2008. 256 с.

${ }^{9}$ Суслов Е. Логика организации музыкальной ткани в двухчастных обработках И.Я. Паницкого. VI-а Всеукраїнська «Музична освіта України: проблеми теорії, методики, практики» та III-я міжнародна «Творчість для народних інструментів композиторів України та зарубіжжяя науково-практичні конференції (ДДПУ ім. I. Франка, 9-10 травня 2013 р., м. Дрогобич) : зб. матер. та тез / ред.-упоряд. А. Душний, Б. Пиц. Дрогобич : Посвіт, 2013. С. 254-262.

Варавина Л. Александр Летунов - композитор и исполнитель. VII-а Всеукраїнська «Музична освіта України: проблеми теорї, методики, практики» та $I V$ міжнародна «Творчість для народних інструментів композиторів України та зарубіжжя» науково-практичні конферениї̈ (ДДПУ ім. І. Франка, 30 квітня - 1 травня 2014 р., м. Дрогобич) : зб. матер. і тез / ред.-упоряд. А. Душний, Б. Пиц. Дрогобич : Посвіт, 2014. С. 86-91. 
США. Чотирнадцять розділів крок за кроком розкривають горизонти історії баяна-акордеона світу, а саме:

- передумови виникнення від кінця XIX до 30-х рр. XX ст.;

- зародження професійної творчості в Австрії та Німеччині у 20-30-х pp. ХХ ст. (Х. Герман) і другої половини ХХ ст. (Г. Бреме, В. Якобі, К. Швен, Г. Катцера, Ю. Ганцера);

- творчість датських композиторів (М. Еллегард, О. Шмідт, В. Хольмбоє, Н. Бентсона, Л. Кайзера, П. Ольсена, П. Ньоргорда, Б. Лорентсена);

- музика для баяна Швеції на прикладі творчості Т. Лундквіста; творчі напрацювання митців Фінляндії (Е. Йокінен, М. Мурто, К. Ахо, М. Линдберг, П. Макконен);

- звернення до композиторів Норвегії (А. Нордхейм), Італії (Л. Беріо), Франції (А. Аббот, Ф. Анжеліс), Польщі (Б. Пшібильський, Б. Довлаш, А. Кшановський, К. Ольчак, Б. Преч), Чехії (І. Фельд), Словаччини (Ю. Хатрик), Японії (Ю. Такахаші, Т. Хосокава);

- окремо автор розкриває горизонти естрадної та джазової музики США (П. Дейро, П. Фроссіні, Е. Галла-Ріні, Ч. Маньянте, А. Ван Дамм, Ф. Марокко), Німеччини (Р. Вюртнер, Ф. Фоссен), Аргентини (А. П'яццолла), Франції (Р. Гальяно) яка становить «золотий фонд» й окремий пласт напрацювання оригінальної творчості для баянаакордеона, показуючи еволюційні засади розвитку репертуарних тенденцій щодо означеного напряму у світі ${ }^{11}$.

Друге видання унаочнює історію виконавства на різновидах гармонік і їхніх сучасних модифікаціях у готово-виборний багатотембровий інструмент із великою амплітудою можливостей та оригінальною творчістю. П’ятнадцять розділів поступово ознайомлюють нас:

- iз різновидами гармоніки; походженням, принципами винайдення (новизною К. Деміана) та поширенням у Західній Європі (кінець XVIII-XIX ст.);

- зі створенням хроматичних гармонік у $30-\mathrm{x}$ рp. XIX ст. (права рука - хроматична; ліва - діатонічна); історичним визначенням народності гармоніки, іiі затребуваністю в соціумі другої половини $\mathrm{XX}$ ст., секретами популярності (такими як престиж, мобільність, стійкість до температури);

- зі становленням і розвитком хроматичної гармоніки з басовоакордовим супроводом (внеском Н. Бєлобородова);

\footnotetext{
${ }^{11}$ Имханицкий М. Музыка зарубежных композиторов для баяна и акордеона : учебное пособие. Москва : РАМ им. Гнесиных, 2004. 376 с. 
- 3 еволюційними процесами розвитку баяна й акордеона 3 готововиборною клавіатурою; розумінням і значенням баяна в Росії та СРСР (репертуаром, виконавцями, виробництвом) першої половини ХХ ст. (творчістю М. Чайкіна, соціальною масовістю й освітнім процесом, зародженням академічного спрямування);

- із камернізацією інструменту від 50-х рp. ХХ ст. до сьогодення (композиторськими та виконавськими аспектами, солістами, ансамблями, оркестрами, педагогами, методичною основою) в колишньому Союзі та зарубіжжі ${ }^{12}$.

Вагомим доробком постає дослідження творчих стереотипів для баяна-акордеона у Білорусі. Окремі розвідки належать М. Сєврюкову, В. Чабану, Л. Скачко, В. Старіковій, Є. Тарас, Д. Чорному, Л. Суховаровій та ін. Серед дисертацій слід відзначити праці В. Чабана «Білоруська баянна школа: становлення, розвиток, сучасний стан (19302000 рр.)» (Мінськ, 2013) $)^{13}$, О. Нємцевої «Популярна музика для баяна и акордеона в контексті розвитку білоруської і світової художньої культури XX-XXI ст.» (Мінськ, 2014), Л. Скачко «Транскрипція в системі сучасного акордеонного мистецтва» (Мінськ, 2016) ${ }^{14}$.

Вивчення репертуару для акордеона важливе для пізнання творчості композиторів-сучасників Європи. Це сприяє виявленню та внесенню до навчальних програм оригінальної музики зарубіжних композиторів, утвердженню та популяризації інструмента у соціумі міжнародної євроінтеграції. У Польщі творчість композиторів Т. Веселовскі (Tadeusz Wesołowski), А. Крзановскі (Andrzej Krzanowski), Є. Мандравскі (Jerzego Mądrawskiego), Б. Довлаша (Bogdana Dowlasza), M. Нізіурскієго (Mirostawa Niziurskiego) досліджують Е. Богуславскі (Edward Boguslawski) «Akordeon w moich doswiadczeniach tworczych» ${ }^{15}$, Є. Мандравскі (Jerzy Mandrawski) «Tworczosc kompozytorska Mirostawa Niziurskiego na akordeon w latach 1994-2002»" ${ }^{16}$, Е. Росінска (Elzbieta Rosinska) «Akordeonistyka polska - zagrozenia i szanse», Є. Грабовска

12 Имханицкий М. История баянного и аккордеонного искусства : учебное пособие. Москва : РАМ им. Гнесиных, 2006. 520 с.

13 Чабан В. Белорусская баянная школа: становление, развитие, современное состояние (1930-2000-е гг.) : автореф. дис. ... докт. искусствов. : 17.00.02. Минск, 2013. $48 \mathrm{c}$.

14 Скачко Л. Транскрипция в системе современного аккордеонного искусства : автореф. дис. ... канд. искусствов. : 17.00.02. Минск, 2016. 27 с.

${ }^{15}$ Boguslawski E. Akordeon w moich doswiadczeniach tworczych. Akordeon u progu XXI wieku / pod red. J. Pichury. Czestochowa, 2003. S. 25-30.

${ }^{16}$ Mandrawski J. Tworczosc kompozytorska Mirostawa Niziurskiego na akordeon w latach 1994-2002. Akordeon u progu XXI wieku / pod red. J. Pichury. Czestochowa, 2003. S. 39-58. 
(Ewa Grabowska) ${ }^{17}$, Е. Слівкієвіч-Цісак (Elwira Śliwkiewicz-Cisak) ${ }^{18}$, M. Кавіорскі (Marek Kawiorski) ${ }^{19}$, П. Шиманський ${ }^{20}$ та ін. Серед праць «Композиторська творчість для акордеону Богдана Довлаша» (2000) €. Мандравскі ${ }^{21}$, «Панорама творчості польських акордеоністів» Е. Росінскої ${ }^{22}$ та ін.

Репертуар литовських композиторів В. Швядаса, В. Лочеріса, В. Богданоса, Й. Тамуленіса, А. Шендероваса, Ж. Мартінайтіте та ін. висвітлюють дописи Д. Васаускене ${ }^{23}$, Е. Габніса ${ }^{24}$, Г. Бальчунаса ${ }^{25}$. Щодо дослідження композиторських традицій Сербіï, то тут варта уваги робота 3. Ракіча «Особливості баянно-акордеонної культури в

${ }^{17}$ Akordeon u progu XXI wieku / pod red. J. Pichury. Czestochowa, 2003. S. 31-38.

18 Śliwkiewicz-Cisak E. Kompozycje z taśmą w twórczości Andrzeja Krzanowskiego. Music Art XXI Century - history, theory, practice: collection of scientific papers Institute of Musical Art Drohobych Ivan Franko State Pedagogical University / edited and compilers A. Dushniy. Drohobych - Kielce - Kaunas - Almaty : Posvit, 2016. S. 221-228.

${ }^{19}$ Mądrawski J., Kawiorski M. Twórczość kompozytorska na akordeon Jerzego Mądrawskiego na podstawie wybranych utworów kameralnych. Music Art XXI Century history, theory, practice: collection of scientific papers Institute of Musical Art Drohobych Ivan Franko State Pedagogical University / edited and compilers A. Dushniy. Drohobych - Kielce - Kaunas - Almaty : Posvit, 2016. S. 209-220.

${ }^{20}$ Шиманський П. Творчість Богдана Довлаша в контексті розвитку баянноакордеонного мистецтва II половини XX століття. Музичне мистеитво XXI століття - історія, теорія, практика: зб. наук. прачь інституту музичного мистецтва Дрогобицького державного педагогічного університету імені Івана Франка / заг. ред. та упоряд. А. Душного. Дрогобич - Кельце - Каунас - Алмати : Посвіт, 2016. С. 198-202.

21 Madrawski J. Twórczość kompozytorska Bogdana Dowlasza na akordeon. Warszawa, 2000. $60 \mathrm{~s}$.

${ }^{22}$ Rosińska E. Panorama polskiej twórczości akordeonowej URL: http://pinkaccordions.homelinux.org/staff/er/docs/panorama.pdf.

${ }_{23}$ Васаускене Д. Репертуар литовских авторов для акордеона. Creativity for folk instruments composers Ukraine and from abroad: collection of materials and theses VI-th International Scientific and Practical Conference (Drohobych Ivan Franko State Pedagogical University, May 7, 2016, Drohobych) / editors-compilers A. Dushniy, B. Pyts. Drohobych : Posvit, 2016. S. 35-42.

${ }^{24}$ Габнис Э. Об аккордеонном искусстве в Литве. VII Всеукрайнська «Музична освіта України: проблеми теорї, методики, практики» та IV міжнародна «Творчість для народних інструментів композиторів Украӥни та зарубіжжя» науково-практичні конференції (ДДПУ ім. І. Франка, 30 квітня - 1 травня 2014 р., м. Дрогобич) : зб. матер. і тез / ред.-упоряд. А. Душний, Б. Пиц. Дрогобич : Посвіт, 2014. C. 19-23.

25 Бальчунас Г. Произведения литовских композиторов для аккордеона, их параллельная связь с развитием исполнительского искусства. Humanities science current issues: Interuniversity collection of Drohobych Ivan Franko State Pedagogical University Young Scientists Research Papers / editors-compilers V. Ilnyzkiy, A. Dushniy, I. Zymomrya. Drohobych : Posvit, 2015. Issue 13. S. 80-87. 
Сербії» ${ }^{26}$, яка розкриває ключові напрями становлення, розвитку та популяризації баянно-акордеонного мистецтва у Сербії, напрацювання різновекторних пластів творчості, виконавства, педагогіки, творчих навчальних центрів.

Однією із затребуваних українських праць нового тисячоліття постає посібник А. Сташевського «Нариси з історії української музики для баяна» (Луганськ, 2006), до якого входять три розділи і ціла низка підрозділів унаочнення історичного феномену розвитку творчості для баяна в Україні. Саме класифікація еволюційної сатисфакції коефіцієнту репертуарного напрацювання взята за основу написання праці, тим самим, як зазначено у передмові, це сприяло «систематизації матеріалу стосовно баянної музики відомих вітчизняних композиторівавангардистів, охопивши практичні всі напрями української (курсив мій - Г. С.) баянної літератури» ${ }^{27}$. Власне, авторське дослідження: розкриває еволюційні процеси як репертуару, так і інструментарію та виконавства, генезис оригінальної музики для гармоніки в Україні, формування репертуару у $20-30-\mathrm{x}$ рp. XX ст.; містить загальну характеристику баянної літератури 40-50-х рр., направлене на взірці творчості М. Різоля, В. Подгорного, В. Дикусарова, К. Мяскова, I. Яшкевича, Г. Шендерьова та ін. і баянних концертів 70-х pp.; характеризує баянну літературу другої половини 70-80-х рр., автор звертається до творчості А. Гайденка, В. Власова, А. Білошицького, Ю. Шамо, В. Зубицького, В. Рунчака та інших постатей кінця XX початку XXI ст.

Вагомим напрацюванням вважається посібник-монографія «Баянна творчість українських композиторів» (Львів, 2011) за авторством Д. Кужелева. Праця характеризує творчість композиторів України другої половини XX - початку XXI ст. для баяна й акордеона. Автор робить висновки щодо становлення баянної творчості в Україні, формування концертного репертуару від 60-70-х рр. до останньої чверті XX - початку XXI ст., до визначення «баянного екстриму» у творчості сучасних композиторів (В. Рунчака, І. Тараненка, Ю. Шамо, Л. Самодаєвої，К. Цепколенко，В.Польової，О.Щетинського). Автор «намагався показати динаміку жанрово-стильової еволюції баянної музики - від простих обробок народних пісень, до нефольклорних моделей та авангардних творів» ${ }^{28}$.

${ }^{26}$ Ракич 3. Особенности развития баянно-аккордеонной культуры в Сербии : автореф. дис. ... канд. искусствоведения : 17.00.02. Москва, 2004. 21 с.

27 Сташевський А. Нариси 3 історії української музики для баяна : навчальний посібник. Луганськ : Поліграфресурс, 2006. С. 3.

28 Кужелєв Д. Баянна творчість українських композиторів : навчальний посібник. Львів : СПОЛОМ, 2011. С. 6. 


\section{2. Оригінальний репертуар українських композиторів у контексті конкурсу «Perpetuum mobile»}

Однією з особливостей популяризації репертуару постає наочне втілення творчості композиторів XXI ст., зокрема у процесі конкурсів і фестивалів. Новаторство репертуару охоплює найрізноманітніші сфери впливу на слухача. Тут і оригінальна творчість (для соло, ансамблів та оркестрів), і перекладення, аранжування й інструментування як прояв елементарної композиторської творчості. Основна мета - реакція слухацької аудиторії на новизну творіння митця, іiі стильове спрямування, передачу художнього образу самими виконавцями у процесі прем'єрного виконання.

Так, засобом популяризації виконавства, новинок творчих інспірацій, прояву нових молодих музикантів постає міжнародний конкурс баяністів-акордеоністів «Perpetuum mobile» який проводиться щорічно у Дрогобичі ${ }^{29}$. Якщо звернутися до історії конкурсу, то за 12 років систематичної діяльності різновекторних важелів баянноакордеонного мистецтва сьогодні стали відомими як нові твори митцівсучасників, так і низка прем'єрних концертних виступів композиторіввиконавців, котрі відбулася саме на «Perpetuum mobile». Серед останніх варто відзначити імена В. Зубицького, В. Власова, В. Губанова, В. Куриленка, Б. Мирончука, Я. Олексіва, В. Рунчака, В. Чумака та ін.

Творчість композитора-баяніста-диригента-організатора Володимира Зубицького масштабна та затребувана акордеонною спільнотою сьогодення. Його твори - Соната № 2 «Слов’янська», «Карпатська сюїта», «Присвячення Астору П’яцоллі», «Джаз-партити № 1, 2», джазвальс «Люблю тебе, Пезаро», «Болгарська сюїта», «Прелюдія та токата», Дитячі сюїти, «Західноукраїнський танок», «Веснянка», «Ріка життя» та ін. постають домінуючим репертуаром на різних етапах навчання та виховання особистості музиканта.

У 2010 p. оргкомітет III міжнародного конкурсу баяністівакордеоністів «Perpetuum mobile» запросив головою журі В. Зубицького. У рамках цього заходу відбувся сольний концерт і майстер-клас маестро. Несподіваною новинкою стала спільна нагорода (диплом) від організаторів конкурсів «Perpetuum mobile» (директор А. Душний) i «Cita di Lanciano» (В. Зубицького) для усіх учасників Дрогобицьких змагань, котрі отримали можливість із 2010 р. систематично брати участь у міжнародному конкурсі акордеоністів у м. Ланчіано (Італія). Як

29 Душний А. Конкурс баянистов-аккордеонистов «Perpetuum mobile» в социокультурном пространстве Украины XXI века («Perpetuum Mobile» Competition of Bayanists-Accordeonists in he Socio-Cultural Space of 21st Century Ukraine). Tradition \& Contemporarity: scientific works Department of Music Academy of Arts Klaipéda University (Lithuania). Klaipèda, 2018. № 13. S. 321-338. 
підсумок, наші учасники-баяністи (акордеоністи) у сольному та колективному музикуванні (про що свідчить мережа Інтернет) вдруге підтвердили високе звання «Лауреата міжнародного конкурсу» й отримали заслужені нагороди та призові місця.

Продовж десяти років маестро Зубицький виступає очільником конкурсу «Perpetuum mobile» та систематично дає авторські сольні концерти у тандемі із дружиною Наталею (ф-но). Як зазначають ЗМI: «Свято продовжив наступний сімейний тандем Наталії (ф-но) та Володимира (баян) Зубицьких, які своєю майстерністю виконання та тактикою передачі емоційно-художнього образу творів змушували зал водночас із їхнім виконанням переживати хвилюючі моменти музичного полотна, що було створене автором В. Зубицьким. Його твори - "Тi ато Pesaro", "Ріка" з циклу "Музика на кінець тисячоліття" та "Від Фанчелі до Гальяно" - настільки вразили публіку, що вона гучними оплесками та вигуками “браво” просто не хотіла відпускати маестро зі сцени»" .

Серед близько вісімдесяти опусів В. Зубицького для баяна особливе місце посідає Концерт для баяна 3 камерним оркестром «Omaggio ad Astor Piazzolla» (1999). У сучасному концертному та педагогічному репертуарі Концерт виступає одним із найбільш затребуваних творів. Так, на VI Міжнародному конкурсі солістів-баяністів і акордеоністів «Кубок Кривбасу» (2006) концерт «Omaggio ad Astor Piazzolla» виявився лідером представлених конкурсних програм ${ }^{31}$. Водночас Концерт «Ommagio ad Astor Piazzolla» (у 3 ч.) був обов'язковим твором IV категорії «концертні виконавці» на X «Perpetuum mobile» (2017) у Дрогобичі, у супроводі камерного оркестру Дрогобицького фахового музичного коледжу ім. В. Барвінського (кер. С. Фендак) ${ }^{32}$.

Цікавим фактом концертної діяльності митця в рамках Дрогобицького конкурсу постає виконавство з оркестром саме згаданого твору: 2011 - 3 Оркестром народних інструментів ім. В. Воєводіна Донецької музичної академії ім. С. Прокоф'єва (кер. А. Нижник); 2017 із камерним оркестром вищезазначеного коледжу. Цього ж року відбувся сімейний концерт (спільно із дружиною Наталею та сином Станіславом

30 Давидов М. Мекка народно-інструментального мистецтва. Украӥнська музична газета. № 3 (81). 2011.; Вл. інф. IV міжнародний конкурс баяністівакордеоністів «Perpetuum mobile». Часопис «Франківець». 2011. № 16 (182).

31 Голяка Г. Твори Володимира Зубицького в сучасному конкурсному репертуарі баяністів URL: http://archive.nbuv.gov.ua/portal/soc_gum/pednauk/ 2010_8/370.pdf.

X-th International bayan-accordion Competition "Perpetuum mobile", II International Scientific and Practical Conference "Music Art XXI century - History, Theory, Practice" (Drohobych Ivan Franko State Pedagogical University, April 29 May 3, 2017 Drohobych): program / editors-compilers A. Dushniy, B. Pyts. Drohobych : Posvit, 2017. $62 \mathrm{~s}$. 
$(\text { флейта) })^{33}$ та презентація новітнього полотна композитора - Народної симфонії єднання «Україна» (І ч. «Червона калина») у виконанні симфонічного оркестру (кер. та дир. С. Фендак) і хору (кер. Б. Бондзяк) ДМК ім. В. Барвінського ${ }^{34}$.

Творчість корифея українського баянного мистецтва, композитора, виконавця, науковця та педагога Віктора Власова увінчана естрадноджазовим спрямуванням із проекцією на сучасне бачення інструменту у сфері неофольклоризму та полістилістики. У процесі конкурсних прослуховувань визначилося ціле гроно пріоритетних творів митця, зокрема Соната-експромт «Буковинська», Фантазія на тему української народної пісні «Взяв би я бандуру», «Ноктюрн» (із присвятою М. Оберюхтіну), Парафраз на народні теми, «Зимовий ескіз», «Веснянка», «Ідилія у мініатюрі», «Посмішка Брамса», «Дитячий альбом естрадних п’єс», «Свято на Молдаванці», «Босса нова», «Мені подобається цей ритм», «Кроки», «Бассо остінато», «Одеський дворик», «Телефонна розмова», «П’ять поглядів на країну ГУЛАГ» та ін.

У 2011 р. було нагороджено О. Лукашевича із Дзержинського музичного коледжу (Росія) дипломом за краще виконання твору В. Власова «Босса нова»; 30 квітня 2014 р. відбулася прем’єра виконання «Елегій» і Концерту «Баян-бенд» за участі професора Володимира Мурзи (баян, Одеса), Свгена Жураського (ф-но) та Юрія Дякунчака (к/б) із Дрогобича ${ }^{35}$; у 2016 р. «Pereptuum mobile» був присвячений 80річчю від дня народження маестро, на якому звучали як нові (наприклад, Кафе «Фанконі» у виконанні квартету народних інструментів «Мурза»), так і відомі твори митця, відбулася творча зустріч із відео-презентацією «Мій баян і кіно» ${ }^{36}$.

${ }^{33}$ Грає сім'я Зубицьких: Володимир Зубицький (баян), Наталія Зубицька (ф-но), Станіслав Зубицький (флейта): Г. Венявський. «Куяв'як»; М. Гарсон. «Джаз-варіації на тему Паганіні»; В.А. Моцарт. «Турецьке рондо»; Ф. Шуберт. «Музичний момент»; Г. Дініку. «Румунський хоровод»; М. Римський-Корсаков - В. Зубицький. «Політ джмеля»; В. Зубицький. «Чардаш», «Від Фанчеллі до Гальяно», «Хмарки», «Ріка життя».

34 Душний А., Пиц Б. Ювілейний X міжнародний конкурс баяністівакордеоністів «Perpetuum mobile». Франківецьь. № 5 (250). 2017. С. 1, 4-5.

VII міжнародний конкурс баяністів-акордеоністів «Perpetuum mobile», VII Всеукраїнська «Музична освіта України: проблеми теорії, методики, практики» та IV міжнародна «Творчість для народних інструментів композиторів України та зарубіжжя» науково-практичні конференції (ДДПУ ім. І. Франка, 30 квітня - 3 травня 2014 р.) : програма / ред.-упоряд. : А. Душний, Б. Пиц. Дрогобич : Посвіт, 2014. 52 с.

IX-th International bayan-accordion Competition "Perpetuum mobile", International "Music Art XXI century - History, Theory, Practice" and VI-th "Creativity for folk instruments composers Ukraine and from abroad" Scientific and Practical Conference (Drohobych Ivan Franko State Pedagogical University, 6-9 of May, 2016, Drohobych) / editors-compilers A. Dushniy, B. Pyts. Drohobych : Posvit, 2016. 52 s. 
Водночас творчість Власова, увінчана фольклорними мотиваціями, характеризується розмаїттям жанрових стереотипів, напрямів i складників. М. Імханіцкий констатує: «Помітна тісна опора на народнопісенні джерела <...> прагнучи максимально точно зберегти їхні основні риси, автор водночас підходить до них творчо сміливо, ініціативно» ${ }^{37}$.

Починаючи із 50-х pp. минулого століття у репертуар баяністів стрімко увірвалися варіації на тему українських народних пісень «Ой, ходила дівчина бережком» (1959), «Ой, за гаєм, гаєм» (1961). Автор переосмислює фольклорні мотиви та поєднує їх із власним інтонаційним матеріалом. Саме такий підхід проявляється у творах «На ярмарку» (1964), «На трійці» (1969) та «На вечірці» (1970), які, за визначенням самого композитора, він написав під враженнями балету «Петрушка» І. Стравінського.

«На ярмарку» композитор вдало відтворює барвисту лінію веселої ярмаркової стихії. Образне мислення проявляється таким чином: «Це усе нагадує базар, ринок, ярмарок. Десь блазень грає на гармошці, якісь скоморохи, лялькова вистава, балаган... Одним словом, на ярмарку усе це!» ${ }^{38}$. «На вечірці» - напевно найбільш затребувана п’єса у репертуарі баяністів і сьогодні. В основі твору лежить відтворення (імітація) звучання балалайки у манері імпровізаційності та грайливості тематизму.

Концертною та віртуозною постає «Веснянка», в основі якої лежить народна тема «А вже весна, а вже красна». Твір збагачений різними ритмічними та динамічними фігураціями, віртуозними пасажами та структурними модифікаціями.

Лінію народності продовжує інтерпретація народних тем у віртуозній композиції «Парафраз на народну тему» (1977). Твір характеризують широкі можливості перетворень народної теми («А ми просо сіяли») на основі багатого арсеналу засобів інтонаційного, гармонічного та структурного варіювання. Особливу винахідливість композитор виявляе у вишуканих метро-ритмічних переосмисленнях теми на фоні частих зі змінним тактовим розміром, а поєднання несистематичних акцентів, форшлагів i синкоп підкреслює гумористично-грайливий характер твору.

Цікаві елементи збагачення музичного матеріалу на основі фольклорних мотивів знаходимо i в інших творах «На трійці», у Фантазії на тему української народної пісні «Взявши би я бандуру», у великих жанрах академічного плану - трьох концертах для баяна

37 Имхиницкий М. Творчество Виктора Власова для баяна и акордеона. Творчість композиторів України для народних інструментів : зб. матер. міжнар. наук.-практ. конф. (Львів, ЛДМА ім. М. Лисенка, 10 квітня 2006) / ред.-упоряд. А. Душний, С. Карась, Б. Пиц. Дрогобич : Посвіт, 2006. С. 47.

${ }^{38}$ Семешко А. Виктор Власов. Киев : Acco-opus, 2004. 112 с. 
3 оркестром, у низці концертних мініатюр (Експромт, Скерцо, Токата, Тарантела та ін.). Яскравий мелодизм, ритмічна пульсація цих п'єс, усесторонне відчуття природи інструменту стало основою їхньої широкої популярності, внесення до численних збірників, антологій, посібників, обов'язкових творів на тому чи іншому конкурсі ${ }^{39}$. Створені на основі фольклорного мелосу п’єси В. Власова відповідають традиційним моделям композиторського стилеутворення баянної творчості 60-70-х pp. XX ст. М. Імханіцкий зазначає: «Зворушливий мелодизм, свіжість гармонічної мови, глибинне відчуття природи інструмента - все це приваблювало увагу до творів Віктора Власова цього періоду» ${ }^{40}$.

Творчість сучасного композитора-авангардиста Володимира Рунчака викликає захопленість, вимагає всесторонньої виконавської обізнаності від музиканта, володіння тонкощами інтерпретації сучасної полістилістичної музичної багатогранності. 30 квітня 2012 р. в рамках конкурсу відбувся творчий вечір композитора за участі солістів Одеської філармонії Георгія Коча (баян) і Наталії Чуприни (ф-но) у сплетінні наукових коментарів та анотацій А. Сташевського. Звучали «Messa da reguiem», «Дві сповіді», «Наслідування Д. Шостаковича» та «Біля портрета I. Стравінського» із сюїти № 1 «Портрети композиторів», Симфонія для баяна та симфонічного оркестру «Страсті за Владиславом». Творчість композитора певною мірою відбиває загальні тенденції сучасного музичного мистецтва щодо переосмислення засобів музичної виразності, трансформації жанровостилістичних і формоутворюючих чинників ${ }^{41}$.

В авторських концертах i програмах конкурсантів різних років звучать твори молодого композитора та науковця Львова Ярослава Олексіва «Токата», «Let's run in jass», «Соната-балада», «Елегія», «У настрої джазу», перие авторське виконання Сюїти «Ніч на полонині» за драматичною поемою О. Олеся (2012), яка у номінації «автор-виконавець» принесла композитору перемогу (диплом I ступеня) на конкурсі «Perpetuum mobile» (2012). Митець як диригент

39 Савчин Г. Фольклорна мотивація у творчості Віктора Власова. Народноінструментальне мистеитво на зламі XX-XXI століть : зб. матер. та тез XI міжнар. наук.-практ. конф. (ДДПУ ім. І. Франка, 08 грудня 2017, м. Дрогобич) / ред.-упоряд. А. Душний, Б. Пиц. Дрогобич : По́світ, 2017. С. 44-45.

${ }^{40}$ Імханицький М. Віктор Власов. Давидов М. Історія виконавства на народних інструментах (Украӥнська академічна школа) : підручник. Київ : НМАУ ім. П. Чайковського, 2005. С. 232-235.

${ }^{41}$ Сташевський А. Баянне мистецтво України: тенденції розвитку оригінальної музики та індивідуальне втілення жанрово-стильового аспекту у творчості Володимира Рунчака : автореф. дис. ... канд. мистецтвознавства : 17.00.03. Київ, 2004. 23 c. 
оркестру українських народних інструментів Львівської НМА ім. М. Лисенка у рамках конкурсу репрезентував «Ліричну фантазію “Яворина”» (2010) та «Українську фантазію» (2011), створену спеціально для цього колективу. «Одкровення» - обов’язковий твір I туру номінації «Концертні виконавці» на $\mathrm{X}$ «Perpetuum mobile» (2017), а його інтерпретаційна модель втілена в авторському виконанні учнів класу (Р. Пунейка, П. Гільченка, I. Сумарука) як еталон виконавсько-філософського мислення та художньої виразності.

Затребуваними в контексті «Perpetuum mobile» постають напрацювання Biктора Губанова, житомирського композитора, виконавця, ансамбліста, педагога. Його доробок становить невід'ємний контент оригінальної баянної літератури та компонувань для різного типу народно-інструментальних колективів. Вальс із «Ретро-сюїти» автора є обов'язковим твором практично для кожного виконавцябаяніста (акордеоніста), часто виконується у конкурсних, фестивальних i концертних програмах, внесений до навчальних програм 3ВО України, уособлює цілісний спектр компоненту сучасного виконавця. Перекладення Вальсу для дуету баяністів здійснив дрогобицький аранжувальник Сергій Максимов ${ }^{42}$. Водночас твір внесений до репертуару «Прикарпатського дуету баяністів» (Віктор Чумак - Сергій Максимов) і є його невід'ємною складовою частиною.

Творчий доробок висвітлює збірка автора «Концертні твори для баяна (акордеона)» $(2004)^{43}$, до якої увійшли «Ретро-сюїта» (І ч. Вальс, II ч. «Коли іде дощ», III ч. «Веселий вікенд») і «Джазова п'єса». У рукописах знаходяться Самба «Мік-Мак», Сонатинка, Вальс-мюзет «У Парижі дощ», Поліритмічний етюд $(3 \times 2)$ пам'яті В. Міхєєва «Струмок життя». Аранжування для тріо баяністів - «Прелюдія у стилі Скрябіна» із трьох п’єс із «Дитячого альбому», «Швидкоплинність», «Шкільний вальс» Володимира Подгорного. Композиції для естрадного квартету (баяна, кларнета, гітари, контрабаса) доповнюють «Heavy Tango» Р. Гальяно, для інструментального тріо (домри, балалайки, баяна) «Черемшина» В. Михайлюка в обробці В. Губанова та ін.

Сольні виступи виконавця й у складі тріо народних інструментів «Болеро» й естрадного ансамблю «Сузір'я блюз» Житомирського музичного училища ім. В. Косенка та Житомирської обласної філармонії ім. С. Ріхтера відповідно відбулися у рамках конкурсів

42 Душний А., Карась С., Пиц Б. Педагогічний репертуар для дуету баяністів : навчальний посібник. Дрогобич : Посвіт, 2007. С. 44-59.

43 Губанов В. Концертні твори для баяна (акордеона) [Ноти]. Тернопіль : Навчальна книга - Богдан, 2004. 36 с. 
«Візерунки Прикарпаття» ${ }^{44}$ (2014) i «Perpetuum mobile» ${ }^{45}$ (2015). Серед творів автора звучали «Ретро-сюїта» (у 3 ч.), Вальс-мюзет, Самба «Мік-Мак», «Українські візерунки», «Черемшина» В. Михайлюка в обробці В. Губанова та ін.

У низці концертних програм постають імена авторів-виконавців Володимира Куриленка («Солодка самотність», «Коли настає ніч»), Бориса Мирончука («Джаз-рок партита», «Циганський вальс», «Циганський король»), Віктора Чумака (варіації на тему лемківської народної пісні «Кедь ми прийшла карта»), Романа Стахніва («Коло.Мийка», «Smile», «Поет мовить» на слова I. Франка, «Без коментарів», Рондо «Пам-парам»), Володимира Шлюбика («Поема», «Прикарпатські наспіви», «Перемишлянський вальс», «Зустріч у місті», Концертний етюд a-moll), Миколи Головчака («Коломийка»), Володимира Клименка (Прелюдія та фуга a-moll «Спогади про Веделя», Концерт для баяна з орк. с-moll), Павла Гільченка (Вальс «Спогад», «Парафраз»), Романа Пунейка («Прелюд», «Дитяча сюїта»: I ч. «Ранок у лісі»; II ч. «Танець лісорубів»; III ч. «Вечірня тиша»), Олексія Бекеші («Dorian Grey», «Присвята Анжелісу»), Володимира Годлевського («Імпровізація у стилі джаз-фольк-року»), Володимира Віцькова («Реальний Настрій», Концертна партита № 2 для готововиборного баяна в 4 ч., «Фінал» із Сонати № 1, Сюїта в естрадноджазовому стилі в 3 ч.: I ч. «3 джазом назавжди»; II ч. «Наслідуючи класиків»; III ч. «Реальний настрій»), твори яких активно виконуються й учасниками конкурсу, популяризуються у навчальних програмах, домінують у фестивальних імпрезах.

\section{ВИСНОВКИ}

Провівши аналіз основних критеріїв вивчення народноінструментального мистецтва сучасності, варто відзначити: дослідницька діяльність ведеться широко та масштабно із залученням як наукового, так і творчого потенціалу; виокремлюються цілі наукові школи у галузі баяна-акордеона; уніфіковується спадщина як

44 VII Всеукраїнський Відкритий конкурс баяністів-акордеоністів «Візерунки Прикарпаття», VIII міжнародна науково-практична конференція «Народноінструментальне мистецтво на зламі XX-XXI століть» (ДДПУ ім. I. Франка, 5-7 грудня 2014 р.) : програма / упоряд. А. Душний, Б. Пиц. Дрогобич : Посвіт, 2014. 32 с.

VIII міжнародний конкурс баяністів-акордеоністів «Perpetuum mobile», VIII Всеукраїнська «Музична освіта України: проблеми теорії, методики, практики» та V міжнародна «Творчість для народних інструментів композиторів України та зарубіжжя» науково-практичні конференції (ДДПУ ім. І. Франка, 30 квітня 3 травня 2015 р.) : програма / ред.-упоряд. А. Душний, Б. Пиц. Дрогобич : Посвіт, 2015. $44 \mathrm{c}$. 
загальноукраїнського, так і регіонального значення для розвитку та популяризації баянно-акордеонного мистецтва.

Нами окреслено пріоритетну лінію наукового висвітлення репертуарного феномену у працях українських і зарубіжних науковців XXI ст. Взяті за основу дослідження сприяють впровадженню напрацювань авторів у навчальний процес, методичну складову частину та повсякденну роботу над удосконаленням репертуарної політики та виконавської техніки крізь призму соціокультурного наслідування сьогодення.

Для унаочнення соціальної значущості репертуарного надбання українських композиторів нами проведено наскрізний аналіз їхньої творчості у контексті міжнародного конкурсу баяністів-акордеоністів «Perpetuum mobile» у Дрогобичі. Ми констатуємо, що оригінальна музика посідає пріоритетну нішу у формуванні виконавської майстерності баяніста-акордеоніста, сприяє розширенню мистецького кругозору індивіда, виявляє придатність музиканта-виконавця до усвідомлення, розуміння та втілення сучасного репертуару баяністамиакордеоністами у контексті української академічної школи.

\section{АНОТАЦІя}

У статті розкривається проблематика репертуару для баяна-акордеона на основі дослідницького феномену України та зарубіжжя. Проводиться лінія наукового осмислення крізь призму дисертаційних досліджень, скомпонованих щодо теорії виконавської майстерності М. Давидова. Увагу привертають фундаментальні праці, довідники, посібники М. Давидова, Д. Кужелева, А. Семешка, А. Сташевського та ін.

Проаналізовано репертуарну палітру на основі українського (окреслено спектр дисертаційних досліджень і пріоритетну посібникову літературу) та зарубіжного досвіду (наведено приклади праць представників Росії, Білорусії, Польщі, Литви, Сербіï).

Доведено популяризацію оригінального репертуару українських композиторів у рамках міжнародного конкурсу баяністів-акордеоністів «Perpetuum mobile». За історію конкурсу свої оригінальні твори представляли композитори-виконавці В. Зубицький, В. Куриленко, Б. Мирончук, Я. Олексів, В. Губанов, В. Чумак, Р. Стахнів, М. Головчак та ін. у концертних програмах i програмах учасників конкурсних прослуховувань. Музика В. Власова та В. Рунчака виконувалася на творчих вечорах митців та у прем'єрних виступах.

\section{SUMMARY}

The article reveals the problems of the repertoire for bayan-accordion based on the research phenomenon of Ukraine and abroad. The line of scientific 
comprehension through the prism of dissertation researches is carried out, arranged in relation to the M. Davydov theory of performing skills. Therefore, attention is drawn to fundamental works, directories, manuals, etc. M. Davydov, D. Kuzhelev, A. Semeshko, A. Stashevsky and others.

Analyzed repertoire palette of research based on Ukrainian and foreign experience. Regarding the first, then the focus is on a number of dissertation research, in which the dominant priority is the composer's work (Yu. Chumak, A. Stashevsky, A. Shamigov, Ya. Oleksiv, M. Bulda, etc.). Spectral analysis of A. Stashevsky works is carried out and D. Kuzhelev, that in light of the establishment, development and defining a modern interpretation repertory analyze trends and argue its multi-vector modifications.

In relation to the second, then we turn to the compositional maxims of Russia (research by A. Mikhailova, U. Mironova, T. Budanova, O. Vasilieva, M. Vlasova, etc., thorough works by M. Imkhanitsky) and Belarus (dissertations of V. Chaban, O. Nemtseva, L. Skachko). We focus on the works of European researchers: Poland (A. Krzanowski, E. Madrawski, E. Rosinska, E. Boguslawski, etc.), Lithuania (D. Vasauskene, E. Gabnis, G. Balčunas), Serbia (Z. Rakic). As a basis for illustrating research imitation we took publications, which most of the mentioned authors cover on the pages of Drohobych scientific publications, in particular - conference proceedings "Creativity for folk instruments composers Ukraine and from abroad" and "Folk-Instrumental Art at the turn of XX-XXI century" recent decades.

Brought popularization of the original repertoire of Ukrainian composers within International Competition bayan-accordion "Perpetuum mobile". Therefore, throughout the history of the competition, composers and performers presented their original works V. Zubitsky, V. Kurylenko, B. Myronchuk, Ya. Oleksiv, V. Gubanov, V. Chumak, R. Stakhniv, M. Holovchak and others, in concert programs and programs of participants of competitive auditions. The music of V. Vlasov and V. Runchak was performed at creative evenings of artists and premieres of leading performers.

The nomination was launched as part of the competition "Authorperformers", which opened a number of new names of composers of different ages (Ya. Oleksiv, V. Godlevsky, V. Vitkov, R. Stakhniv, O. Bekeshi, R. Puneyko, P. Hilchenko, V. Shlyubyk, V. Klimenko), and the judges of their work were the masters of the Ukrainian bayan school of composition V. Zubitsky, V. Vlasov, A. Stashevsky, V. Runchak, and abroad E. Madrawski (Poland), G. Hermosa (Spain), F. Deschamps (France).

Definitely research activity of repertoire tendencies of Ukrainian composers for bayan-accordion is carried out on a large scale involving both scientific and creative potential, whole scientific schools of this branch are singled out, the heritage is unified as an all-Ukrainian one and regional 
significance of development and popularization of bayan-accordion art. Therefore, the active phase of chambering of the repertoire is carried out, identification of its modern stylistic features and the modern-avant-garde dominant in the light of the academic present.

Outlined priority line of scientific coverage of the repertoire phenomenon in the works of Ukrainian and foreign scientists of the XXI century. Key research, in our opinion, contribute to the implementation of the works of the authors in the educational process, methodical component and daily work to improve repertoire policy and performing techniques through the prism of socio-cultural imitation of the present.

So, original music occupies a priority niche in the formation of the performance skills of bayanists-accordionist, contributes to the expansion of the artistic horizon of the individual, reveals the suitability of the musicianperformer for awareness, understanding and embodiment of the modern repertoire by bayan-accordion in the context of the Ukrainian academic school.

\section{ЛІТЕРАТУРА}

1. Давидов М. Історія виконавства на народних інструментах (Українська академічна школа) : підручник. Київ : НМАУ ім. П.І. Чайковського, 2010. 592 с.

2. Душний А., Пиц Б. Львівська школа баянно-акордеонного мистецтва : довідник. Дрогобич : Посвіт, 2010. 216 с.

3. Имханицкий М. История баянного и аккордеонного искусства : учебное пособие. Москва : РАМ им. Гнесиных, 2006. 520 с.

4. Имханицкий М. Музыка зарубежных композиторов для баяна и аккордеона : учебное пособие. Москва : РАМ им. Гнесиных, 2004. $376 \mathrm{c}$.

5. Кужелєв Д. Баянна творчість українських композиторів : навчальний посібник. Львів : СПОЛОМ, 2011. 206 с.

6. Семешко А. Баянно-акордеонне мистецтво України на зламі XX-XXI століть : довідник. Тернопіль : Навчальна книга - Богдан, 2009. $244 \mathrm{c}$.

7. Сташевський А. Нариси з історії української музики для баяна : навчальний посібник. Луганськ : Поліграфресурс, 2006. 152 с.

8. Akordeon u progu XXI wieku / pod redakcja J. Pichury. Czestochowa, 2003. 90 s.

\section{Information about the author: Ulych (Savchyn) H. V., Postgraduate Student Institute of Musical Art} of Drohobych Ivan Franko State Pedagogical University 24, I. Franko str., Drohobych, Lviv region, Ukraine 